\title{
Sleep-disordered breathing in nonobese diabetic subjects with autonomic neuropathy
}

\author{
P. Bottini*, M.L. Dottorini*, M. Cristina Cordoni*, G. Casucci*, C. Tantucci ${ }^{\#}$
}

Sleep-disordered breathing in nonobese diabetic subjects with autonomic neuropathy. P. Bottini, M.L. Dottorini, M. Cristina Cordoni, G. Casucci, C. Tantucci. (C) ERS Journals Ltd 2003.

ABSTRACT: To assess the occurrence and nature of sleep-disordered breathing (SDB) in 26 adult, nonobese diabetics (18 with autonomic neuropathy (DAN+) (age 45 (41-50) yrs; body mass index (BMI) $24.1(22-26) \mathrm{kg} \cdot \mathrm{m}^{-2}$ ) and eight without autonomic neuropathy (DAN-) (age $45(35-55)$ yrs; BMI $\left.24.8(23-26) \mathrm{kg}^{-\mathrm{m}^{-2}}\right)$ ) overnight full sleep studies and measurements of central and peripheral carbon dioxide $\left(\mathrm{CO}_{2}\right)$ chemosensitivity were performed.

$\mathrm{DAN}+$ were divided in two subgroups, according to the presence (DAN+PH+; $\mathrm{n}=10$ ) or absence (DAN $+\mathrm{PH}-; \mathrm{n}=8$ ) of postural hypotension. Ten normal subjects were studied as controls (age $42(36-48)$ yrs; BMI $\left.24.4(23-25) \mathrm{kg} \cdot \mathrm{m}^{-2}\right)$.

In contrast to DAN- and controls, who did not show SDB, five DAN+ (four DAN + PH- and one DAN $+\mathbf{P H}+$ ) had an apnoea/hypopnoea index $\geqslant 10$ and four DAN + (two DAN $+\mathbf{P H}$ - and two DAN $+\mathbf{P H}+$ ) had an apnoea index $\geqslant 5$. All the events were obstructive, occurring mainly during rapid eye movement (REM) sleep. Ten DAN + exhibited a mean lowest oxygen saturation $<90 \%$ during REM sleep. No periodic breathing or central sleep apnoeas were found in $\mathrm{DAN}+\mathrm{PH}+$, although they had an enhanced central chemoresponsiveness to $\mathrm{CO}_{2}$. Both DAN+ subgroups showed a marked reduction in peripheral $\mathrm{CO}_{2}$ chemosensitivity.

In conclusion, adult nonobese diabetics with autonomic neuropathy, independent of the severity of their dysautonomy, have obstructive sleep apnoea/hypopnoea with a frequency $>30 \%$. A decrease in peripheral carbon dioxide chemosensitivity prevents adult nonobese diabetics with autonomic neuropathy and postural hypotension from experiencing posthyperventilatory central sleep apnoea, despite an increased hypercapnic central drive.

Eur Respir J 2003; 22: 654-660.
*Dept of Internal Medicine and EndocrineMetabolic Sciences, University of Perugia, Perugia, and ${ }^{\#}$ Respiratory Medicine, University of Brescia, Brescia, Italy.

Correspondence: C. Tantucci

I Medicina, University of Brescia

Piazzale Spedali Civili, 1

25123, Brescia

Italy

Fax: 3930396011

E-mail: tantucci@med.unibs.it

Keywords: Autonomic neuropathy control of breathing

diabetes

sleep apnoea

Received: August 52002

Accepted after revision: May 282003

This work was supported by a grant from Ministry of Education, University and Research (MIUR) of Italy.
A high incidence of sudden deaths has been observed in diabetic patients with diabetic autonomic neuropathy (DAN), in particular when they are asleep [1-4]. To investigate the potential role of sleep-disordered breathing (SDB), several studies have been performed in the past to assess respiratory disturbances during sleep in these patients [5-8]. First, GUILLEMINAULT et al. [5] found obstructive sleep apnoeas (OSA) in two and central sleep apnoeas (CSA) in one of four type-1 diabetics with DAN. Subsequently, REES et al. [6] described sleep apnoea syndrome in three of eight diabetics with DAN, but not in eight diabetics without DAN. Later on, although CATTERALL et al. [7] did not find differences in the apnoea index (AI) between diabetics with and without DAN, NEUMANN et al. [8] reported a significant correlation between the number of oxygen desaturations during sleep and the gravity of DAN. Recently, FICKER et al. [9] showed OSA in $26 \%$ of diabetics with DAN; however, some of them were $>60$ yrs, obese and not selected according to the severity of DAN. Therefore, the first aim of the present study was to assess the occurrence of SDB and its nature in adult, nonobese diabetic subjects with autonomic neuropathy of different severities. Diabetics suffering from severe dysautonomy and postural hypotension have been shown to have an enhanced central chemosensitivity to carbon dioxide $\left(\mathrm{CO}_{2}\right)$ $[10,11]$. Since an increased hypercapnic central drive is thought to promote periodic breathing and CSA during stages 1 and 2 of sleep [12-14], the second aim was to establish if diabetic subjects with severe autonomic neuropathy and postural hypotension had periodic breathing and/or central sleep apnoea.

\section{Methods}

\section{Subjects}

Twenty-six adult diabetic patients, 18 with autonomic neuropathy (DAN+; age 45 (95\% confidence interval (CI) 41-50) yrs, body mass index (BMI) $\left.24.1(22-26) \mathrm{kg} \cdot \mathrm{m}^{-2}\right)$ and eight without autonomic neuropathy (DAN-; age 45 (35-55) yrs, BMI $\left.24.8(23-26) \mathrm{kg} \cdot \mathrm{m}^{-2}\right)$, were consecutively recruited from the Dipartimento di Medicina Interna e Scienze Endocrine e Metaboliche (DiMISEM) of the University of Perugia (Perugia, Italy) (table 1). The subjects were enrolled after they had given fully informed consent and all subjects completed the study. The protocol was approved by the local ethical committee and was in accordance with the Helsinki Declaration. All the patients were insulin treated, with regular insulin before each meal and intermediate-acting insulin at bedtime or with regular insulin before breakfast and lunch 
Table 1.-Clinical features and pulmonary functional parameters of the subjects

\begin{tabular}{|c|c|c|c|c|}
\hline & Control & DAN- & $\mathrm{DAN}+\mathrm{PH}-$ & $\mathrm{DAN}+\mathrm{PH}+$ \\
\hline Subjects M:F & $9: 1$ & $8: 0$ & $7: 1$ & $8: 2$ \\
\hline Age yrs & $42.0(36.3-47.7)$ & $45.3(35.3-55.2)$ & $43.8(35.0-52.5)$ & $46.9(40.8-52.9)$ \\
\hline $\mathrm{BMI} \mathrm{kg} \cdot \mathrm{m}^{-2}$ & $24.4(23.0-25.0)$ & $24.8(23.1-25.7)$ & $23.8(20.2-26.2)$ & $24.5(22.4-26.0)$ \\
\hline Type of diabetes $1 / 2$ & & $6 / 2$ & $6 / 2$ & $8 / 2$ \\
\hline Duration of diabetes yrs & & $13.5(9.4-17.6)$ & $18.5(11.2-25.8)$ & $18.8(11.2-25.8)$ \\
\hline $\begin{array}{l}\text { Diabetic autonomic } \\
\text { neuropathy score }\end{array}$ & & $0.3(0.0-0.6)$ & $4.3(3.5-5.0)^{* * *}$ & $7.6(6.8-8.6) * * *, \# \# \#$ \\
\hline $\mathrm{HbAlc} \%$ & & $7.3(6.4-7.6)$ & $7.6(6.0-8.3)$ & $7.9(6.9-8.1)$ \\
\hline VC $\%$ pred & $116(105-127)$ & $110(97-123)$ & $108(100-116)$ & $99(85-113)^{-\oplus}$ \\
\hline IC $\%$ pred & $114(101-126)$ & $105(87-123)$ & $97(88-105)^{\text {ศศ }}$ & $87(73-101)^{* *, \text {,ศ }}$ \\
\hline FRC $\%$ pred & $128(82-164)$ & $118(95-140)$ & $113(97-129)$ & $126(103-148)$ \\
\hline RV \% pred & $125(107-143)$ & $120(96-144)$ & $106(91-121)$ & $135(107-134)$ \\
\hline TLC $\%$ pred & $114(103-125)$ & $113(98-127)$ & $103(93-112)^{* \text {, }}$ & $107(92-122)$ \\
\hline FEV1 \% pred & $109(98-121)$ & $107(95-118)$ & $99(92-105)^{\text {ตฯ }}$ & $100(85-114)^{\text {ศศ }}$ \\
\hline FEV1/FVC \% & $79(77-82)$ & $83(77-89)$ & $80(77-83)$ & $84(80-88)$ \\
\hline FEF $25-75 \% \%$ pred & $89(72-108)$ & $96(75-116)$ & $86(76-91)$ & $95(72-117)$ \\
\hline $\mathrm{Sa}, \mathrm{O}_{2} \%$ & $98(97.1-98.5)$ & $98(97.1-98.3)$ & $98(97.0-98.6)$ & $98(97.2-98.2)$ \\
\hline$P$ et, $\mathrm{CO}_{2} \mathrm{mmHg}$ & $38(36.2-39.6)$ & $38(34.5-39.9)$ & $38(36.4-39.6)$ & $38(35.7-39.1)$ \\
\hline$P 0.1 \mathrm{cmH}_{2} \mathrm{O}$ & $1.77(1.54-1.99)$ & $1.77(1.59-2.00)$ & $1.80(1.63-1.97)$ & $1.89(1.68-2.10)$ \\
\hline$V^{\prime} \mathrm{E} \mathrm{L} \cdot \mathrm{min}^{-1}$ & $13.5(11.6-15.6)$ & $13.8(11.9-14.5)$ & $14.5(12.2-16.7)$ & $14.7(12.8-16.7)$ \\
\hline$V \mathrm{~T} \mathrm{~L}$ & $0.93(0.81-1.05)$ & $0.86(0.76-0.96)$ & $0.77(0.69-0.86)$ & $0.76(0.66-0.87)$ \\
\hline $\mathrm{RR}$ breath $\cdot \mathrm{min}^{-1}$ & $14.6(12.4-17.0)$ & $16.2(14.3-17.7)$ & $19.2(15.3-23.0)$ & $19.7(17.6-22.0)$ \\
\hline$\Delta P 0.1 / \Delta P$ et, $\mathrm{CO}_{2} \mathrm{cmH}_{2} \mathrm{O} \cdot \mathrm{mmHg}^{-1}$ & $0.49(0.36-0.62)$ & $0.41(0.28-0.53)$ & $0.27(0.14-0.39)$ & 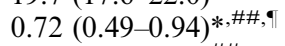 \\
\hline$\Delta V^{\prime} \mathrm{E} / \Delta P \mathrm{et}, \mathrm{CO}_{2} \mathrm{~L} \cdot \mathrm{min}^{-1} \cdot \mathrm{mmHg}^{-1}$ & $3.35(2.89-3.81)^{\# \#}$ & $2.73(1.91-3.55)^{\#}$ & $1.66(1.72-2.19)$ & $3.29(2.92-3.65)^{\# \#}$ \\
\hline
\end{tabular}

Data are presented as mean ( $95 \%$ confidence intervals). DAN-: adult, nonobese diabetics, without autonomic neuropathy; DAN+PH-: adult, nonobese diabetics, with autonomic neuropathy and without postural hypotension; DAN+PH+: adult, nonobese diabetics, with autonomic neuropathy and postural hypotension; M: male; F: female; BMI: body mass index; HbAlc: glycated haemoglobin (normal values in nondiabetics 3.8-5.5\%); VC: vital capacity; \% pred: per cent predicted; IC: inspiratory capacity; FRC: functional residual capacity; RV: residual volume; TLC: total lung capacity; FEV1: forced expiratory volume in the one second; FVC: forced vital capacity; FEF25-75\%: forced expiratory flow between 25$75 \%$ of FVC; $\mathrm{Sa}, \mathrm{O}_{2}$ : arterial oxygen saturation; $P$ et, $\mathrm{CO}_{2}$ : end-tidal carbon dioxide pressure; $P 0.1$ : mouth occlusion pressure at $100 \mathrm{~ms}$ after the beginning of inspiration; $V^{\prime} \mathrm{E}$ : minute ventilation; $V \mathrm{~T}$ : tidal volume; RR: respiratory rate; $\Delta P 0.1 / \Delta P$ et, $\mathrm{CO}_{2}$ : slope of the linear relationship between $P 0.1$ and $P$ et, $\mathrm{CO}_{2} ; \Delta V^{\prime} \mathrm{E} / \Delta P$ et, $\mathrm{CO}_{2}$ : slope of the linear relathionship between $V^{\prime} \mathrm{E}$ and $P$ et, $\mathrm{CO}_{2}$ during $\mathrm{CO}_{2}$ rebreathing. *: $\mathrm{p}<0.05$ versus $\mathrm{DAN}-\mathrm{C}^{*}$ *: $\mathrm{p}<0.01$ versus DAN-; ${ }^{* * *}: \mathrm{p}<0.001$ versus $\mathrm{DAN}-{ }^{\#}: \mathrm{p}<0.05$ versus $\mathrm{DAN}+\mathrm{PH}-{ }^{\# \#}: \mathrm{p}<0.01$ versus $\mathrm{DAN}+\mathrm{PH}-{ }^{\# \# \#}: \mathrm{p}<0.001$ versus $\mathrm{DAN}+\mathrm{PH}-{ }^{\circ}{ }^{\circ}$ $\mathrm{p}=0.05$ versus control; ${ }^{\top \uparrow}: \mathrm{p}<0.01$ versus control.

and 30/70 mixed insulin before dinner. Autonomic neuropathy was assessed by the standard cardiovascular tests, i.e. deep breathing, Valsalva manoeuvre, lying to standing, postural hypotension and sustained handgrip [15]. Each test was scored according to the literature [16] and the patients were considered positive for autonomic neuropathy if the total score was $\geqslant 4$. Ten of $18 \mathrm{DAN}+$ diabetics had a severe alteration of the cardiovascular reflexes, including postural hypotension (a fall in systolic blood pressure $\geqslant 30 \mathrm{mmHg}$ ) and/or impaired response to sustained handgrip $(\mathrm{DAN}+\mathrm{PH}+)$. The remaining eight $\mathrm{DAN}+$ patients had an impairment in at least two tests out of deep breathing, lying to standing and Valsalva manoeuvre, but had a normal response to both systolic blood pressure to standing and diastolic blood pressure to sustained handgrip (DAN+PH-) $[10,11$, 17]. Two patients in the DAN- group, five patients in the $\mathrm{DAN}+\mathrm{PH}-$ group and 10 patients in the $\mathrm{DAN}+\mathrm{PH}+$ group had pre-proliferative retinopathy, and one patient in the $\mathrm{DAN}+\mathrm{PH}+$ group had proliferative retinopathy. Two patients in the DAN- group, six patients in the DAN+PHgroup and 10 patients in the $\mathrm{DAN}+\mathrm{PH}+$ group had microalbuminuria, and two patients in the $\mathrm{DAN}+\mathrm{PH}+$ group had macroproteinuria, however, none of them had serum creatinine $>1.8 \mathrm{mg} \cdot \mathrm{dL}^{-1}$. Four subjects in the DANgroup, five patients in the $\mathrm{DAN}+\mathrm{PH}$ - group and eight subjects in the DAN $+\mathrm{PH}+$ group were taking angiotensionconverting enzyme inhibitors (essentially enalapril at a dosage of 10 or $20 \mathrm{mg}$ once daily) for slight hypertension or to prevent the worsening of diabetic nephropathy. None of the patients studied had any signs or symptoms of metabolic or endocrine diseases other than diabetes. No respiratory symptoms were observed or reported at the time of the study. Morphological abnormalities of the nose and throat were excluded by an otorhinolaryngological examination before the study. Ten nondiabetic, normal subjects, recruited from the University of Perugia staff and matched for sex, age and weight, were studied as the control group.

\section{Study design}

Pulmonary function tests. All diabetic and control subjects performed pulmonary function tests, including spirometry and flow/volume curves, using a pneumotachograph linear up to 13.6 L·s ${ }^{-1}$ (model 3813; Hans-Rudolph, Kansas City, MO, USA), and had measurements of lung volume taken using the multiple breath nitrogen washout technique. All tests were carried out with subjects in the sitting position, wearing a noseclip and breathing through a mouthpiece connected to a computerised measuring system (MedGraphics 1070; Medical Graphics Co., St Paul, MN, USA). The predicted values for volumes and flows were those proposed by the European Community for Coal and Steel [18]. Minute ventilation $\left(V^{\prime} \mathrm{E}\right)$, tidal volume $(V \mathrm{~T})$ and respiratory rate $(\mathrm{RR})$ were measured at rest from the time-integrated flow signal, breathing room air in the seated position using a two-way nonrebreathing, balloon shutter occlusion valve (Hans-Rudolph). Randomly, every four to eight breaths, the inspiratory line was silently closed during expiration by automatically inflating the balloon via a computer-supported pneumatic system (Respiratory Pressure Module MedGraphics; Medical Graphics Co.). Mouth pressure was measured during the subsequent occluded 
inspiration from a side port in the occlusion valve that was connected to a pressure transducer $\left( \pm 150 \mathrm{cmH}_{2} \mathrm{O}\right.$; Validyne Inc., Northridge, CA, USA) through a noncompliant polyethylene catheter (internal diameter $1.4 \mathrm{~mm}$, length $95 \mathrm{~cm}$ ). The value of mouth pressure calculated at $100 \mathrm{~ms}$ after the beginning of the inspiration with occluded airways $(P 0.1)$ was displayed by the computer (Respiratory Pressure Module MedGraphics; Medical Graphics Co.) [19]. Baseline P0.1 was computed as the mean of at least eight values, after having rejected the lowest and the highest. $\mathrm{CO}_{2}$ was continuously sampled at the mouth and the expiratory end-tidal $\mathrm{CO}_{2}$ pressure $\left(P\right.$ et, $\left.\mathrm{CO}_{2}\right)$ was measured breath-by-breath by a rapid infrared $\mathrm{CO}_{2}$ analyser (Gas Analyser Module, CPX MedGraphics; Medical Graphics Co.). At a flow rate of $1 \mathrm{~L} \cdot \mathrm{s}^{-1}$, the resistance of the rebreathing circuit was $1.1 \mathrm{cmH}_{2} \mathrm{O} \cdot \mathrm{L}^{-1} \cdot \mathrm{s}^{-1}$.

Central and peripheral $\mathrm{CO}_{2}$ chemosensitivity. The same circuit was used to assess the $\mathrm{CO}_{2}$ central and peripheral chemosensitivity in diabetic and control subjects. Each subject, after $5 \mathrm{~min}$ of resting ventilation breathing room air, was connected at residual volume to a 6-L anaesthetic bag filled with either a gas mixture of $15 \% \mathrm{CO}_{2}$ and $85 \%$ oxygen $\left(\mathrm{O}_{2}\right)$ or air. Immediately after, the subject was requested to perform a rapid inspiratory vital capacity manoeuvre, inhaling, in a random order, air or the gas mixture, and, subsequently, once switched again to room air, to breathe normally. The test was repeated six times and on three occasions the gas mixture was inhaled. Each subject rested for $\sim 5$ min during each test. The peripheral $\mathrm{CO}_{2}$ chemosensitivity was evaluated by computing the slope of the linear relationship between $V^{\prime} \mathrm{E}$ and $P$ et, $\mathrm{CO}_{2}$ values measured breath-by-breath from the second to sixth $V \mathrm{~T}$ following the gas mixture inhalation [20].

Central $\mathrm{CO}_{2}$ chemosensitivity was assessed by the rebreathing test performed according to the method of READ [21]. While sitting, after a 5-min period of adaptation to the circuit, each subject started to breathe a gas mixture $\left(7 \% \mathrm{CO}_{2}\right.$ and $93 \% \mathrm{O}_{2}$ ) from a 6-L anaesthetic bag for 4-6 min. During the test, every four to five breaths, $P 0.1$ was obtained following the occlusion manoeuvre, and $V^{\prime} \mathrm{E}, V \mathrm{~T}$ and $\mathrm{RR}$ were calculated from the data averaged from the four breaths preceding each occlusion. For each rebreathing test, $V^{\prime} E$ and $P 0.1$ were plotted against $P$ et, $\mathrm{CO}_{2}$, and data were fitted according to the least-squared method. The slope and intercept of the linear regression were computed on each occasion. The coefficient of correlation was $>0.97$ in all subjects. The plasma glucose concentration was measured at baseline and at the end of the rebreathing test in all diabetic patients by means of a Beckman Glucose Analyser (Beckman Instruments, Palo Alto, CA, USA).

Sleep study. Diabetic and control subjects underwent a sleep study according to the recommendations of the American Sleep Disorders Association [22]. The study was always performed between 23:00 and 06:30 $\mathrm{h}$ and after administration of insulin in diabetics, by means of a NightOwl Polygraph Senior (Respironics Inc., Murrysville, PA, USA). Polysomnographic recordings obtained included: electroencephalogram (EEG; O1A2, C3A2); electrooculogram; electromyogram of the chin, nasal and oral airflow (by thermistors); abdomen and rib cage movements (by inductive plethysmography); oxygen saturation (by finger probe); snoring (by microphone); body movements (by accelerometer); body posture; and electrocardiogram.

The assessment of SDB was essentially focused on apnoea/ hypopnoea events and, as an oesophageal balloon was not used, on EEG arousals as an expression of neural activation probably related to progressive inspiratory efforts in the presence of an increased upper airway resistance. Data were recorded in real time and analysed by the VitaRESP Analysis System (RT Data Acquisition Software; Respironics Inc.).

Apnoeas were defined as a cessation of airflow lasting $>10 \mathrm{~s}$ with a fall in baseline arterial haemoglobin oxygen saturation $\left(\mathrm{Sa}, \mathrm{O}_{2}\right) \geqslant 4 \%$ and hypopnoeas were defined as a reduction in thoraco-abdominal movements $\geqslant 50 \%$ with a fall in baseline of $\mathrm{Sa}, \mathrm{O}_{2} \geqslant 2 \%$. The AI and the apnoea/hypopnoea index (AHI) were calculated as the number of apnoeas and apnoeas plus hypopnoeas, respectively, per hour of the total sleep time. Apnoeas and hypopnoeas were classified as obstructive when the absence or reduction of airflow occurred in the presence of continuing respiratory effort. The oxygen desaturation index reflected the number of $\mathrm{Sa}_{\mathrm{a}} \mathrm{O}_{2}$ falls $\geqslant 4 \%$ compared with baseline per hour of the total sleep time. Mean lowest $\mathrm{Sa}_{2} \mathrm{O}_{2}$ $\left(\mathrm{MLSa}, \mathrm{O}_{2}\right)$ was calculated by averaging the 10 lowest values occurring during the events. Arousals were identified by changes in EEG tracing and divided into macroarousals (mainly reflecting the sleep macrostructure) and microarousals (essentially reflecting respiratory efforts) if they lasted $>1$ min or $<1$ min, respectively. Periods of rapid eye movement (REM) and non-REM (NREM) sleep were identified using the standard criteria [23]. An expert physician, trained in sleep studies, carefully reviewed all tracings, and the automated analysis and scoring were corrected by hand, when necessary, to ensure the reliability of the findings.

SDB was defined as the occurrence of five or more obstructed (or absent) breathing events per hour of sleep, including any combination of obstructive (or central) apnoeas/hypopnoeas or respiratory effort-related arousals.

Daytime hypersomnolence was assessed on the basis of the answers to three subjective questions on sleepiness [24].

\section{Statistical analysis}

Differences between groups were assessed using analysis of variance. Since the assumption about scatter of data could not be made, a two-tailed unpaired nonparametric test (Mann-Whitney U-test) was used to make comparisons between groups. Linear regression analysis was performed according to the least-square method. A probability value of 0.05 was considered significant. Results are expressed as mean $(95 \% \mathrm{CI})$.

\section{Results}

\section{Pulmonary function tests}

Static and dynamic lung volumes and parameters obtained from the maximal flow/volume curve were in the normal range in all groups of diabetic subjects and controls (table 1).

\section{Sleep study}

Two diabetic subjects (one DAN+PH- and one DAN+ $\mathrm{PH}+$ ) did not perform the sleep study satisfactorily because of technical reasons and were excluded from analysis. The duration of sleep and its characteristics in diabetic and control subjects who completed the sleep study are shown in table 2 .

In contrast to DAN- and controls, who did not show SDB, two DAN+PH- and two DAN+PH+ had an $\mathrm{AI} \geqslant 5$, and four $\mathrm{DAN}+\mathrm{PH}+$ and one DAN+PH- had an AHI $\geqslant 10$ (fig. 1a). The events were obstructive and no periodic breathing and/or central CSAs were observed in DAN+ and especially in $\mathrm{DAN}+\mathrm{PH}+$ (fig. 1b). The obstructive events occurred mainly during REM sleep.

DAN+ showed AI and AHI values higher than those of 
Table 2.-Clinical features and characteristics of sleep in control and diabetic subjects who completed the sleep study

\begin{tabular}{|c|c|c|c|c|}
\hline & Control & DAN- & $\mathrm{DAN}+\mathrm{PH}-$ & $\mathrm{DAN}+\mathrm{PH}+$ \\
\hline Subjects M:F & $9: 1$ & $8: 0$ & $7: 0$ & $8: 1$ \\
\hline Age yrs & $42.0(36.3-47.7)$ & $45.3(35.3-55.2)$ & $45.3(35.7-54.8)$ & $48.0(41.2-54.3)$ \\
\hline $\mathrm{BMI} \mathrm{kg} \cdot \mathrm{m}^{-2}$ & $24.4(23.0-25.0)$ & $24.8(23.1-25.7)$ & $24.0(19.8-26.3)$ & $24.1(22.0-26.0)$ \\
\hline Diabetic autonomic neuropathy score & & $0.3(0.0-0.6)$ & $4.3(3.9-5.2)^{* * *}$ & $7.4(6.6-8.5)^{* * *, \#}$ \\
\hline Glycaemia $\mathrm{mg} \cdot \mathrm{dL}^{-1}$ at $23: 00 \mathrm{~h}^{\#}$ & & $167(121-213)$ & $176(124-228)$ & $208(155-260)$ \\
\hline Glycaemia $\mathrm{mg} \cdot \mathrm{dL}^{-1}$ at $06: 30 \mathrm{~h}^{\#}$ & & $139(123-154)$ & $163(127-199)$ & $170(131-204)$ \\
\hline Total sleep time min & $399(332-469)$ & $370(299-411)$ & $370(299-441)$ & $384(321-448)$ \\
\hline REM sleep $\%$ & $20(16-24)$ & $17(14-18)$ & $19(17-22)$ & $19(16-23)$ \\
\hline Latency min & $21(8-35)$ & $15(3-27)$ & $18(7-29)$ & $17(6-28)$ \\
\hline Wake after sleep onset min & $37(15-61)$ & $39(18-59)$ & $55(28-80)$ & $48(29-67)$ \\
\hline Macroarousals n & $5.1(3.2-7.9)$ & $6.5(4.4-8.6)$ & $7.6(3.4-11.8)$ & $6.6(3.7-9.4)$ \\
\hline Microarousals events $\cdot \mathrm{h}^{-1}$ & $1.1(0.3-1.9)$ & $1.3(-0.1-2.2)$ & $7.3(3.8-11.1)^{*}$ & $8.9(2.7-12.2)$ \\
\hline AI events $\cdot h^{-1}$ & $0.2(-0.2-1.1)$ & $0.3(-0.2-0.9)$ & $3.7(-1.9-9.4)$ & $3.3(0.2-6.5)$ \\
\hline AHI events $\cdot h^{-1}$ & $2.2(-0.1-4.1)$ & $2.8(0.1-5.5)$ & $8.1(-1.9-18.1)$ & $11.1(3.3-19.0)^{*}$ \\
\hline ODI events $\cdot h^{-1}$ & $0.3(-0.8-1.1)$ & $1.2(-0.1-2.4)$ & $6.5(-1.5-14.6)^{*}$ & $7.8(1.4-14.2)^{*}$ \\
\hline Subjects with $\mathrm{Sa}_{\mathrm{a}} \mathrm{O}_{2}<90 \%$ during NREM n & 0 & 0 & 4 & 3 \\
\hline Subjects with $\mathrm{Sa}_{\mathrm{a}} \mathrm{O}_{2}<90 \%$ during REM n & 0 & 0 & 5 & 5 \\
\hline
\end{tabular}

Data are presented as mean (95\% confidence interval). DAN-: adult, nonobese diabetics, without autonomic neuropathy; DAN+PH-: adult, nonobese diabetics, with autonomic neuropathy and without postural hypotension; DAN+PH+: adult, nonobese diabetics, with autonomic neuropathy and postural hypotension; M: male; F: female; REM: rapid eye movement; AI: apnoea index; AHI: apnoea/hypopnoea index; ODI: oxygen desaturation index; $\mathrm{Sa}, \mathrm{O}_{2}$ : arterial oxygen saturation; NREM: non-REM. ${ }^{\#}$ : glycaemic values at the beginning and at the end of the sleep study. *: $\mathrm{p}<0.05$ versus control and DAN-; ***: $\mathrm{p}<0.001$ versus $\mathrm{DAN}-{ }^{\#}: \mathrm{p}<0.001$ versus $\mathrm{DAN}+\mathrm{PH}-$.
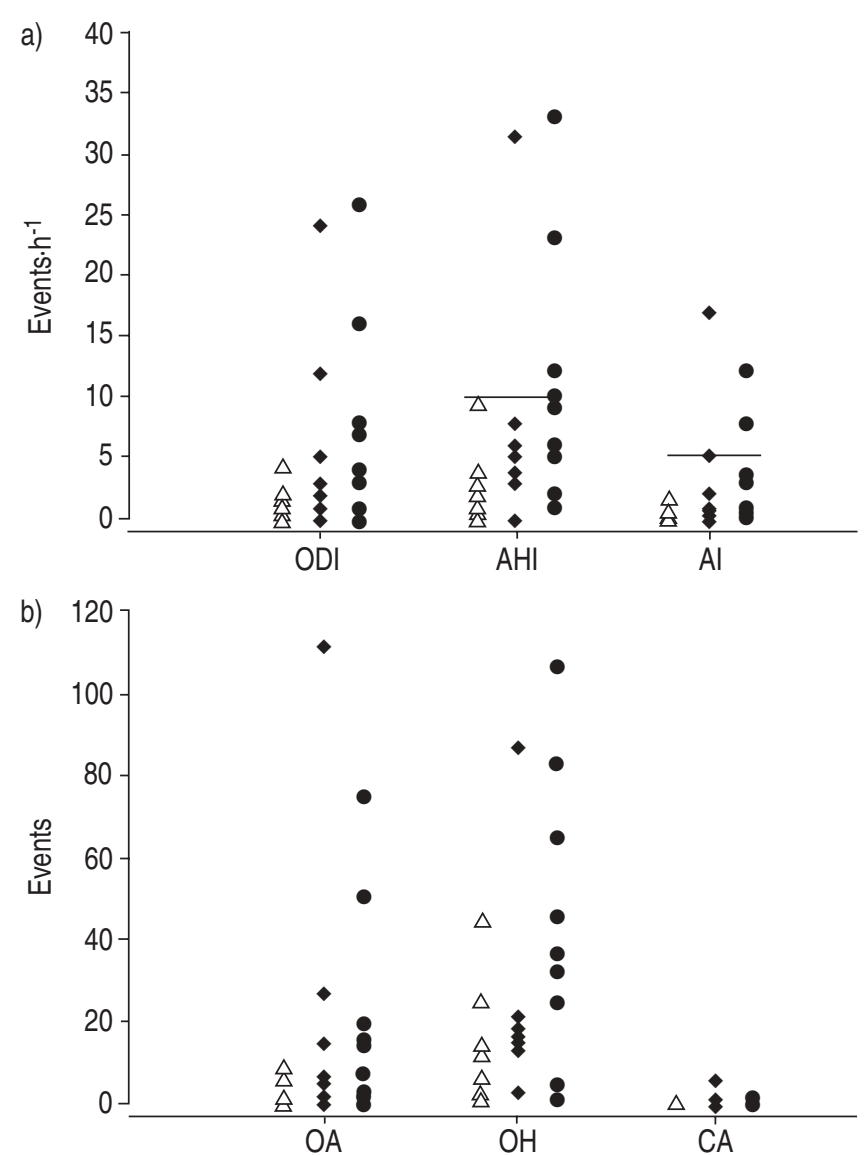

Fig. 1.-a) Individual values of oxygen desaturation index (ODI), apnoea/hypopnoea index (AHI) and apnoea index (AI), and b) events of obstructive apnoea $(\mathrm{OA})$ and hypopnoea $(\mathrm{OH})$ and central apnoea (CA) obtained from adult, nonobese diabetics, without autonomic neuropathy $(\triangle)$, adult, nonobese diabetics, with autonomic neuropathy and without postural hypotension $(\diamond)$ and adult, nonobese diabetics, with autonomic neuropathy and postural hypotension ( during the sleep study.
DAN-, on average amounting to $3.5(0.0-6.1)$ versus 0.3 $(-0.2-0.9)$ and $9.8(4.4-15.3)$ versus $2.8(0.1-5.5)$, respectively $(\mathrm{p}<0.05)$. No DAN- had values of $\mathrm{MLSa}, \mathrm{O}_{2}<90 \%$ either during NREM or REM sleep, while $10 \mathrm{DAN}+$ exhibited values of $\mathrm{MLS} \mathrm{a}_{2} \mathrm{O}_{2}<90 \%$ during REM sleep. In two DAN+, values of $\mathrm{MLSa}, \mathrm{O}_{2}<80 \%$ were recorded.

Marcoarousals (n) and microarousals (events $\cdot \mathrm{h}^{-1}$ ), independent from apnoea/hypopnoea episodes, were reported for all groups in table 2. DAN- and DAN+ without obstructive sleep apnoeas/hypopnoeas (OSAH) never had an incidence of macroarousals $>10 \cdot$ total sleep time ${ }^{-1}$ and of microarousals $>5 \cdot h^{-1}$. Self-reported daytime hypersomnolence was found only in one DAN+PH- subject with OSAH. No diabetic subjects suffered from hypoglycaemia during the sleep study (table 2)

\section{Control of breathing}

Baseline values of $P 0.1, V^{\prime} \mathrm{E}, V \mathrm{~T}$ and RR for the different groups of diabetic subjects and controls are displayed in table 1 .

\section{Central carbon dioxide chemosensitivity}

The increase in the neuromuscular output to hypercapnic stimulation $\left(\triangle P 0.1 / \Delta P\right.$ et, $\left.\mathrm{CO}_{2}\right)$ was greater in $\mathrm{DAN}+\mathrm{PH}+$ than in DAN+PH- $(\mathrm{p}<0.01), \mathrm{DAN}-(\mathrm{p}<0.05)$ and controls $(\mathrm{p}=0.05)$ (table 1). The increment in the ventilatory response to $\mathrm{CO}_{2}$ $\left(\Delta V^{\prime} \mathrm{E} / \Delta P\right.$ et, $\left.\mathrm{CO}_{2}\right)$ exhibited by $\mathrm{DAN}+\mathrm{PH}+$ was higher than that shown by $\mathrm{DAN}+\mathrm{PH}-(\mathrm{p}<0.01)$. In addition, controls $(\mathrm{p}<0.01)$ and DAN- $(\mathrm{p}<0.05)$ had $\Delta V^{\prime} \mathrm{E} / \Delta P$ et, $\mathrm{CO}_{2}$ higher than that of DAN+PH- (table 1).

\section{Peripheral carbon dioxide chemosensitivity}

Neither diabetics nor controls complained of noxious taste, cough or unpleasant sensation during the $\mathrm{CO}_{2}$ inhalation, and the tests were easily accomplished by each subject. The slope 


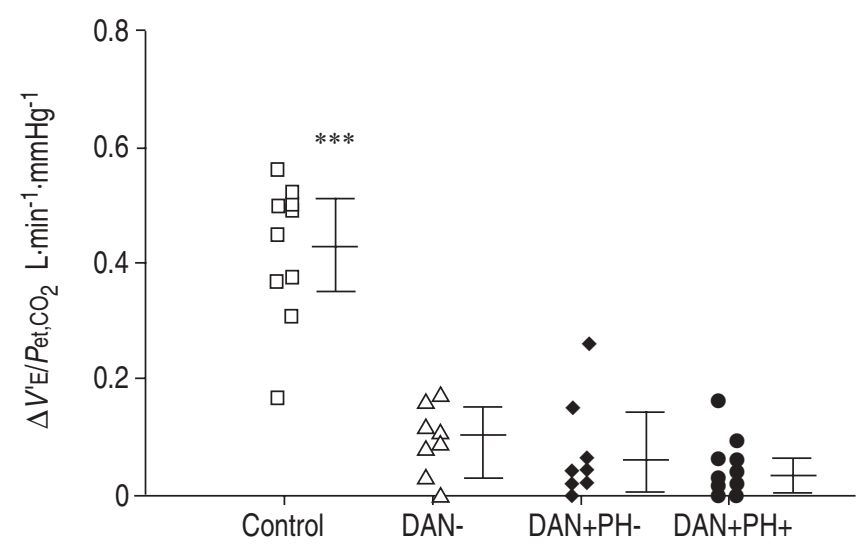

Fig. 2. - Ventilatory response to peripheral carbon dioxide $\left(\mathrm{CO}_{2}\right)$ stimulation (change in minute ventilation $\left(\Delta V^{\prime} \mathrm{E}\right) /$ change in expiratory end-tidal $\mathrm{CO}_{2}$ pressure $\left(\Delta P\right.$ et, $\left.\left.\mathrm{CO}_{2}\right)\right)$ observed in the control group and different diabetic groups (DAN-: adult, nonobese diabetics, without autonomic neuropathy; DAN+PH-: adult, nonobese diabetics, with autonomic neuropathy and without postural hypotension; and $\mathrm{DAN}+\mathrm{PH}+$ : adult, nonobese diabetics, with autonomic neuropathy and postural hypotension). Data are presented as individual values and mean values with $95 \%$ confidence intervals. ${ }^{* * *}: \mathrm{p}<0.001$ versus all diabetic groups.

of the linear relationship between $V^{\prime} \mathrm{E}$ and $P$ et, $\mathrm{CO}_{2}\left(\Delta V^{\prime} \mathrm{E} /\right.$ $\Delta P$ et, $\left.\mathrm{CO}_{2}\right)$ amounted to $0.06(0-0.14)$ and $0.03(0-0.07)$ $\mathrm{L} \cdot \mathrm{min}^{-1} \cdot \mathrm{mmHg}^{-1}$ for the DAN+PH- and DAN $+\mathrm{PH}+$ groups, respectively, and it was markedly lower than that of control, equal to $0.42(0.34-0.51) \mathrm{L} \cdot \mathrm{min}^{-1} \cdot \mathrm{mmHg}^{-1} \quad(\mathrm{p}<0.001)$. In addition, DAN- had a low $\Delta V^{\prime} \mathrm{E} / \Delta P$ et, $\mathrm{CO}_{2}$, equal to 0.09 (0.04-0.14) $\mathrm{L} \cdot \mathrm{min}^{-1} \cdot \mathrm{mmHg}^{-1}(\mathrm{p}<0.001$ versus control) (fig. 2).

\section{Discussion}

The main findings of the present study are as follows: 1) $\mathrm{DAN}+$ patients, independent of the severity of their autonomic neuropathy, have OSAH with a frequency between 30\% (five of 16 with AHI $\geqslant 10$ ) and 25\% (four of 16 with $\mathrm{AI} \geqslant 5)$; 2) $\mathrm{DAN}+\mathrm{PH}+$, despite an increased hypercapnic central inspiratory drive, do not show posthyperventilatory CSA; and 3) DAN+ exhibit a markedly reduced $\mathrm{CO}_{2}$ peripheral chemosensitivity.

OSAH is believed to result from the presence and/or interaction of an anatomical and a functional factor. The anatomical factor is due to the narrowing of the upper airways (UA) and the functional factor is due to the reduced effectiveness of the UA dilator muscles during sleep, often in the presence of an increased UA collapsibility. In the diabetic subjects with autonomic neuropathy who had no anatomic alterations and/or obesity, the functional factors seem to be crucial. This is also because the events were more frequent during REM sleep, when the tonic and phasic activities of the UA dilator muscles are deeply reduced, even in nonapnoeic subjects. Activation of the UA dilator muscles, which comprise $>10$ pairs with complex interactions, depends on a variety of central and peripheral stimuli. The latter, acting on different types of receptor, may elicit reflexes, which travel through either somatic or vegetative fibres and help to maintain the UA dilator muscle tone during wakefulness as well as during sleep. Several types of receptors have been identified in the UA and those related to the mechanosensitive endings have been classified as receptors responding to changes in transmural pressure (pressure receptors), temperature (flow/cold receptors) and degree of muscle contraction (drive receptors) [25]. The characteristics of the afferent fibres have not yet been precisely defined, but evidence exists suggesting that they are type $\mathrm{C}$ amyelinic fibres [26].

Although the role of the reflex activity following stimulation of the mechanoreceptors and particularly the pressure receptors [27] is still controversial in OSAH, dysfunction of such receptors, which appears more severe in apnoeic than snorer subjects [28], is expected to facilitate the occurrence of OSAH $[29,30]$. Indeed, topical pharyngeal anaesthesia with lidocaine induces OSAH in snorers [31], but does not worsen OSAH in apnoeic subjects $[32,33]$, although it may increase the duration of apnoeas [34].

The evidence that amyelinic fibres carrying autonomic afferents directly control the threshold of the mechanoreceptors activation [35] may help to explain the present findings in DAN+.

FICKER et al. [9] observed the presence of OSA (AHI $\geqslant 10$ ) in six of $23 \mathrm{DAN}+(26 \%)$. However, two of these DAN+with OSA were obese $\left(\right.$ BMI $\left.\geqslant 29 \mathrm{~kg} \cdot \mathrm{m}^{-2}\right)$ and three were $>60 \mathrm{yrs}$. Moreover, the severity of the autonomic neuropathy was not defined in DAN+ with and without OSAH. In contrast, the current data have been obtained in a cohort of younger and nonobese DAN+, carefully selected according to the severity of their dysautonomy. Nevertheless, by eliminating important bias, the results of the present study substantiate the findings of FICKER et al. [9] and reinforce the idea that the dysautonomy may favour per se the occurrence of OSAH in diabetic patients.

Furthermore, these findings indicate the need of assessing the UA reflexes in diabetic patients with autonomic neuropathy and, in general, support a role for the UA reflexes in the pathogenesis and natural history of OSAH.

However, other potential mechanisms, such as changes in the control of the UA muscles at the level of the brainstem, related to abnormalities in autonomic regulation, could be involved. In fact, a sufficient coordination between the drive to the UA dilating muscles and to the inspiratory muscles is crucial to maintain the UA patency, especially in REM sleep [36].

The prevalence of SDB has been assessed in many studies, with figures that need to be interpreted according to the criteria adopted and the subjects tested. One of the most comprehensive studies on the age-specific prevalence of OSAH showed that $15 \%$ of $30-60$-yr-old males (and $18 \%$ of $40-49$-yr-old males) had OSAH defined as AHI $\geqslant 10$ in a large sample representative of the general population [37]. In contrast, in the present study, hypopnoea was identified by the presence of a discernible reduction in airflow signal accompanied by a decrease in $\mathrm{Sa}, \mathrm{O}_{2}>4 \%$. However, it is likely that a substantial, though not available, number of obese $\left(\mathrm{BMI} \geqslant 29 \mathrm{~kg} \cdot \mathrm{m}^{-2}\right.$ ) subjects were recruited, as the authors stated that obesity was strongly associated with the presence of SDB [37]. In a similar population sample (middle-aged males), BEARPARK et al. [38] found a prevalence of OSAH (respiratory disturbance index $\geqslant 10$ ) of $8.5 \%$ in Australia, but the data did not indicate how many subjects were symptomatic. In addition, an Italian study reported a prevalence of OSAH (AHI $\geqslant 10$ and a history of snoring every night) of $\sim 5 \%$ in 40-59-yr-old males [39]. Therefore, a frequency of OSAH $(A H I \geqslant 10$ ) equal to $33 \%$ (five of 15 males) in adult, nonobese male DAN+ appears abnormally high compared with figures reported in age- and sex-matched samples from the general population, suggesting a role for dysautonomy in the SBD observed in these subjects.

The second finding of the present study is the absence of $\mathrm{CSA}$ in $\mathrm{DAN}+\mathrm{PH}+$ who exhibit an enhanced $\mathrm{CO}_{2}$ central chemosensitivity $[10,11]$. In different clinical conditions, such as congestive chronic heart failure [14, 40], acromegaly [12] and the idiopathic CSA [13], an increased hypercapnic central 
drive has been shown to be associated with periodic breathing and/or CSA during sleep stages I and II. The underlying mechanism of this SDB, which invariably occurs after periods of hyperventilation, has been clarified and relies on the excessive responsiveness of the respiratory centres to $\mathrm{CO}_{2}[41$, 42]. However, as previously observed in the idiopathic CSA [13], an increase in the peripheral rather than central $\mathrm{CO}_{2}$ chemosensitivity appears to be more relevant in determining the posthyperventilatory central apnoeas. In fact, the ventilatory modulation following the acute "breath-by-breath" and "intra-breath" arterial $\mathrm{CO}_{2}$ tension $\left(\mathrm{Pa}_{\mathrm{a}} \mathrm{CO}_{2}\right)$ changes, which is crucial for eliciting a rapid hyperventilatory response, is mainly related to the peripheral chemoreceptors' $\mathrm{CO}_{2}$ sensitivity $[43,44]$. Accordingly, the substantial decrease in the peripheral $\mathrm{CO}_{2}$ chemosensitivity found in $\mathrm{DAN}+$ may well explain the lack of CSA in the group of $\mathrm{DAN}+\mathrm{PH}+$, despite their enhanced central responsiveness to $\mathrm{CO}_{2}$.

In line with this reasoning, the $P$ et, $\mathrm{CO}_{2}$ of the $\mathrm{DAN}+\mathrm{PH}+$ group was normal and not lower than that observed in the other diabetic groups and controls (table 1), suggesting the absence of arterial hypocapnia, the pathogenetic role of which is of paramount importance for developing posthyperventilatory CSA $[41,42]$. Although arterial $\mathrm{Pa}, \mathrm{CO}_{2}$ was not measured in these subjects, it is widely accepted that, in the absence of lung disease and in the presence of an adequate "plateau", as in the diabetics in this study, $P$ et, $\mathrm{CO}_{2}$ reflects satisfactorily alveolar $\mathrm{CO}_{2}$ pressure and, thus, $\mathrm{Pa}, \mathrm{CO}_{2}$ [45].

The marked reduction in the peripheral chemoresponsiveness to $\mathrm{CO}_{2}$ shown by DAN+ may possibly be ascribed to the damage of the parasympathetic nervous fibres that normally convey afferents from the carotid bodies to the respiratory centres, in line with what has been reported in animals and humans [46, 47].

It is difficult, however, to explain such a reduction in DAN-. Indeed, while in DAN+ the peripheral chemoresponsiveness to hypoxia is also diminished [48], it is better preserved in DAN- [49]. Further studies are needed to clarify this aspect in DAN-.

\section{Limitations of the study}

In this study, nasal and oral airflow was evaluated by thermistors. It is well recognised that thermistors can be inaccurate for quantifying hypopnoeas [50] and that a nasal cannula, recording nasal pressure oscillations, would be preferable as a flow-measuring device. In any case, thermistors would have caused an underdetection of hypopnoeas in all subjects and particularly in DAN+ who showed a larger number of events. Thus, the authors do not believe that this could influence the meaning of the data obtained in this study.

These results of this study, however, have to be confirmed in a larger population of diabetic patients who also deserve to be evaluated by more adequate techniques for hypopnoeas and upper airway resistance episodes.

\section{Conclusions}

In diabetic subjects, autonomic neuropathy does not appear to induce, when severe, posthyperventilatory central sleep apnoea, although it is associated with a relatively high frequency of obstructive sleep hypopnoea/apnoeas. The underlying mechanism has to be elucidated, but could be related to an impairment of the upper airway reflexes, possibly due to alterations of the autonomic nervous fibres involved in their regulation.

\section{References}

1. Ewing DJ, Campbell IW, Clarke BF. Mortality in diabetic autonomic neuropathy. Lancet 1978; i: 601-603.

2. Srinivasan G, Sanders G. Cardiorespiratory arrest in diabetes. Lancet 1978; i: 935-936.

3. Watkins PJ, MacKay LD. Cardiac denervation in diabetic neuropathy. Ann Intern Med 1980; 2: 304-307.

4. Page MM, Watkins PJ. Cardiorespiratory arrest and diabetic autonomic neuropathy. Lancet 1990; i: 14-16.

5. Guilleminault C, Briskin JG, Greenfield MS, Silvestri R. The impact of autonomic nervous system dysfunction on breathing during sleep. Sleep 1981; 4: 263-278.

6. Rees PJ, Prior JG, Cochrane GM, Clark TJ. Sleep apnoea in diabetic patients with autonomic neuropathy. JR Soc Med 1981; 74: 192-195.

7. Catterall JR, Calverley PMA, Ewing DJ, Shapiro CM, Clarke BF, NJ Douglas. Breathing, sleep, and diabetic autonomic neuropathy. Diabetes 1984; 33: 1025-1027.

8. Neumann C, Martinez D, Schmid H. Nocturnal oxygen desaturation in diabetic patients with severe autonomic neuropathy. Diab Res Clin Pract 1995; 28: 97-102.

9. Ficker JH, Dertinger SH, Siegfried W, et al. Obstructive sleep apnoea and diabetes mellitus: the role of cardiovascular autonomic neuropathy. Eur Respir J 1998; 11: 14-19.

10. Tantucci C, Scionti L, Bottini P, et al. Influence of autonomic neuropathy of different severity on the hypercapnic drive to breathing in diabetic patients. Chest 1997; 112: $145-153$.

11. Tantucci C, Bottini P, Fiorani C, et al. Cerebrovascular reactivity and hypercapnic respiratory drive in diabetic autonomic neuropathy. J Appl Physiol 2001; 90: 889896.

12. Grunstein RR, Ho KY, Berthon-Jones M, Stewart D, Sullivan CE. Central sleep apnea is associated with increased ventilatory response to carbon dioxide and hypersecretion of growth hormone in patients with acromegaly. Am $J$ Respir Crit Care Med 1994; 150: 496-502.

13. Xie A, Rutherford R, Rankin F, Wong B, Bradley D. Hypocapnia and increased ventilatory responsiveness in patients with idiopathic central sleep apnea. Am J Respir Crit Care Med 1995; 152: 1950-1955.

14. Javaheri S. A mechanism of central sleep apnea in patients with heart failure. $N$ Engl J Med 1999; 341: 949-954.

15. Ewing DJ, Clarke BF. Diagnosis and management of diabetic autonomic neuropathy. BMJ 1982; 285: 916-918.

16. Bellavere F, Bosello G, Fedele D, Cardone C, Ferri M. Diagnosis and management of diabetic autonomic neuropathy (Letter). BMJ 1983; 287: 261 .

17. Porcellati F, Fanelli CG, Bottini P, et al. Mechanism of arterial hypotension after therapeutic dose of subcutaneous insulin in diabetic autonomic neuropathy. Diabetes 1993; 42: 1055-1064.

18. Quanjer PhH, Tammeling GJ, Cotes JE, et al. Lung volumes and forced ventilatory flows: report of the Working Party "Standardization of lung function test", European Community for Coal and Steel. Eur Respir J 1993; 6: Suppl. 16, 5-40.

19. Whitelaw WA, Derenne JP, Milic-Emili J. Occlusion pressure as a measure of respiratory center output in conscious man. Respir Physiol 1975; 23: 181-199.

20. Gabel RA, Kronenborg RS, Severinghaus JW. Vital capacity breaths of $5 \%$ and $15 \% \mathrm{CO}_{2}$ in $\mathrm{N}_{2}$ or $\mathrm{O}_{2}$ to test carotid chemosensitivity. Respir Physiol 1973; 17: 195-208.

21. Read DJC. A clinical method for assessing the ventilatory response to carbon dioxide. Aust Ann Med 1967; 16: 20.

22. American Sleep Disorders Standards of Practice Committee. Practice parameters for the indications for polysomnography and related procedures. Sleep 1997; 20: 406-422.

23. Rechtschaffen A, Kale A. A manual of standardized terminology, techniques and scoring system for sleep stages of human subjects. Publ. No. 204. Washington DC, National Institutes of Health, 1968. 
24. Guilleminault C, Stoohs R, Duncan S. Snoring (I): daytime sleepiness in regular heavy snorers. Chest 1991; 99: 40-48.

25. Widdicombe J. Upper airway reflexes. Curr Opin Pulm Med 1998; 4: 376-382.

26. Friberg D, Gazelius B, Hokfelt T, Nordlander B. Abnormal afferent nerve endings in the soft palatal mucosa of sleep apneics and habitual snorers. Regul Pept 1997; 71: 29-36.

27. Mathew OP, Ghosh TK. Role of airway afferents on upper airway muscle activity. In: Dempsey JA, Pack AI, eds. Lung Biology in Health and Disease, vol 79 - Regulation of Breathing. New York, Marcel Dekker, Inc., 1995; pp. 511541.

28. Deegan PC, McNicholas WT. Pathophysiology of obstructive sleep apnea. In: McNicholas WT, ed. Respiratory Disorders During Sleep. Sheffield, Clare Wheatcroft, UK Publisher, 1998; vol 3, monograph 10, pp. 28-62.

29. Horner RL. Motor control of pharyngeal musculature and implications for the pathogenesis of obstructive sleep apnea. Sleep 1996; 19: 827-853.

30. Mathew OP, Sant'Ambrogio FB. Laryngeal reflexes. In: Mathew OP, Sant'Ambrogio G, eds. Respiratory Function of the Upper Airway. New York, Marcel Dekker, Inc., 1988; pp. 259-302.

31. Chadwich GA, Crowley P, Fitzgerald MX, O'Regan RG, McNicholas WT. Obstructive sleep apnea following topical oropharyngeal anesthesia in loud snorers. Am Rev Respir Dis 1991; 143: 810-813.

32. Deegan PC, Mulloy E, McNicholas WT. Topical oropharyngeal anesthesia in patients with obstructive sleep apnea syndrome. Am J Respir Crit Care Med 1995; 151: 1108-1115.

33. Berry RB, McNellis MI, Kouchi K, Light RW. Upper airway anesthesia reduces phasic genioglossus activity during sleep apnea. Am J Respir Crit Care Med 1997; 156: 127-132.

34. Cala SJ, Sliwinski P, Cosio MG, Kimoff RJ. Effect of topical upper airway anesthesia on apnea duration through the night in obstructive sleep apnea. J Appl Physiol 1996; 81: 26182626.

35. Akoev GN. Catecholamines, acetylcholine and excitability of mechanoreceptors. Prog Neurobiol 1980; 15: 269-294.

36. Hudgel DW, Harasik T. Fluctuation in timing of upper airway and chest wall inspiratory muscle activity in obstructive sleep apnea. J Appl Physiol 1990; 69: 443-450.

37. Young TB, Palta M, Dempsey JA, Skatrud J, Weber S, Badr S. The occurrence of sleep-disordered breathing among middle-aged adults. $N$ Engl J Med 1993; 328: 1230-1235.
38. Bearpark H, Elliott L, Grunstein R, et al. Snoring and sleep apnea. A population study in Australian men. Am J Respir Crit Care Med 1995; 151: 1459-1465.

39. Cirignotta F, D'Alessandro R, Partinen M, et al. Prevalence of every night snoring and obstructive sleep apnoeas among 30-69-yr-old men in Bologna, Italy. Acta Neurol Scand 1989; 79: $366-372$.

40. Wilcox I, Grunstein RR, Collins FL, Berthon-Jones M, Kelly DT, Sullivan CE. The role of central chemosensitivity in central apnea of heart failure. Sleep 1993; 6: S37-S38.

41. Xie A, Wong B, Phillipson EA, Slutski AS, Bradley TD. Interaction of hyperventilation and arousal in the pathogenesis of idiopathic central sleep apnea. Am J Respir Crit Care Med 1994; 250: 489-495.

42. Naughton MT, Bernard DC, Tam A, Rutherford R, Bradley TD. The role of hyperventilation in the pathogenesis of central sleep apnea in patients with congestive heart failure. Am Rev Respir Dis 1993; 148: 330-338.

43. Black AMS, Torrance RW. Respiratory oscillations in chemoreceptor discharge in the control of breathing. Respir Physiol 1971; 13: 221-237.

44. Carroll JL, Canet E, Bureau MA. Dynamic ventilatory response to $\mathrm{CO}_{2}$ in the awake lamb: role of the carotid chemoreceptors. J Appl Physiol 1991; 71: 2198-2205.

45. Bhavani-Shankar K, Kumar AY, Moseley HSL, AhyeeHallsworth R. Terminology and the current limitations of time capnography: a brief review. J Clin Monit 1995; 11: $175-182$

46. McClean PA, Phillipson EA, Martinez D, Zamel N. Single breath of $\mathrm{CO}_{2}$ as a clinical test of the peripheral chemoreflex. J Appl Physiol 1988; 64: 84-89.

47. Honda Y, Watanabe S, Hashizume I, et al. Hypoxic chemosensitivity in asthmatic patients two decades after carotid body resection. J Appl Physiol 1979; 46: 632638 .

48. Sobotka PA, Liss HP, Vinik AI. Impaired hypoxic ventilatory drive in diabetic patients with autonomic neuropathy. $J$ Clin Endocrinol Metab 1985; 62: 658-663.

49. Montserrat JM, Cochrane GM, Wolf C, Picado C, Roca J, Augusti Vidal A. Ventilatory control in diabetes mellitus. Eur J Respir Dis 1985; 67: 112-117.

50. Farré R, Montserrat JM, Rotger M, Ballester E, Navajas D. Accuracy of thermistors and thermocouples as flowmeasuring devices for detecting hypopnoeas. Eur Respir $J$ 1998; 11: 179-182. 